\title{
Se-Bearing Colloidal Particles Produced by Sulfate-Reducing Bacteria and Sulfide-Oxidizing Bacteria: TEM Study
}

\author{
Huifang $\mathrm{Xu}^{1}$, Larry L. Barton ${ }^{2}$ \\ ${ }^{1}$ NASA Astrobiology Institute, Department of Geoscience, University of Wisconsin-Madison, Madison, USA \\ ${ }^{2}$ Department of Biology, the University of New Mexico, Albuquerque, USA \\ Email: hfxu@geology.wisc.edu
}

Received April 10, 2012; revised May 10, 2012; accepted June 10, 2013

Copyright (C) 2013 Huifang Xu, Larry L. Barton. This is an open access article distributed under the Creative Commons Attribution License, which permits unrestricted use, distribution, and reproduction in any medium, provided the original work is properly cited.

\begin{abstract}
As determined by transmission electron microscopy (TEM), the reduction of selenate and selenite by Desulfovibrio desulfuricans, a sulfate-reducing bacterium, produces spherical (Se, S) sub-micro particles outside the cell. The particles are crystalline or amorphous, depending on medium composition. Amorphous-like Se-rich spherical particles may also occur inside the bacterial cells. The bacteria are more active in the reduction of selenite than selenate. The Desulfovibrio desulfuricans bacterium is able to extract $\mathrm{S}$ in the $(\mathrm{S}, \mathrm{Se})$ solid solution particles and transform $\mathrm{S}$-rich particles into Se-rich and Se crystals. Photoautotrophs, such as Chromatium spp., are able to oxidize sulfide $\left(\mathrm{S}^{2-}\right)$. When the bacteria grow in sulfide- and selenide-bearing environments, they produce amorphous-like $(\mathrm{S}, \mathrm{Se})$ globules inside the cells. TEM results show that compositional zonation in the (S, Se) globules occur in Chromatium spp. collected from a top sediment layer of a Se-contaminated pond. $\mathrm{S}^{2-}$ may be from the products of sulfate-reducing bacteria. Both the sulfate-reducing bacteria and photosynthetic Chromatium metabolize S preferentially over Se. It is proposed that the S-rich zones are formed during photosynthesis (day) period, and the Se-rich zones are formed during respiration active (night) period. The results indicate that both Desulfovibrio desulfuricans and Chromatium spp. are able to immobilize the oxidized selenium (selenate and/or selenite) in the forms of elemental selenium and (Se, S) solid solutions. The bacteria reduce $\mathrm{S}$ in the $(\mathrm{Se}, \mathrm{S})$ particles and further enrich $\mathrm{Se}$ in the crystalline particles. The reduced $\mathrm{S}$ combines with $\mathrm{Fe}^{2+}$ to form amorphous FeS.
\end{abstract}

Keywords: Selenium; Sulfate-Reducing Bacteria; Sulfide-Oxidizing Bacteria; Transmission Electron Microscopy

\section{Introduction}

Selenium $\left({ }^{79} \mathrm{Se}\right)$ is a fission product of nuclear fuel with a half-life time of 65,000 years. Oxidative alteration of spent nuclear fuel will result in the formation of selenate $\left(\mathrm{SeO}_{4}^{2-}\right)$ and selenite $\left(\mathrm{SeO}_{3}^{2-}\right)$ oxy-anions together with uranyl oxy-cation in solution. The selenium oxyanions in natural environment are highly toxic to living systems if the concentration of the oxy-anion is high [1]. Sorption of the anions on clays and other minerals are extremely low. Because they are chemically and radiologically toxic, it is important to immobilize the aqueous selenium oxyanoins and uranyl species.

Sulfate-reducing bacteria are able to reduce sulfate and other oxidized oxy-anions such as selenate, selenite, and uranyl oxy-cation $\left(\mathrm{UO}_{2}^{2+}\right)[2-5]$. It is proposed that the reduction mechanism is a dissimilatory reduction [6]. In general, the reduction potentials of redox pairs (at $\mathrm{pH} 7$ ) utilized by bacteria are within the range of $-0.7 \mathrm{eV}$ to $+1.36 \mathrm{eV}$. Most reports about selenate or selenite reduction by bacteria only focus on solution changes, and do not on elemental selenium as the reaction product $[2,5]$. The elemental Se produced by Desulfovibrio desulfuricans was reported by Tomei et al. [4], and their results indicate that reduction of selenate and selenite can occur under conditions where metabolism has no influence on electron acceptor activity by the culture [4]. The results also show no evidence of $\mathrm{H}_{2} \mathrm{Se}$ production by Desulfovibrio desulfuricans in the presence of selenate or selenite [4]. In this paper, we investigate conditions responsible for reduction of selenate and selenite outside the bacterial cells.

Anaerobic photoautotrophic Chromatium spp. is able to oxidize sulfide $\left(\mathrm{S}^{2-}\right)$ using light. Bacteria grown in 
sulfide-bearing system can produce amorphous-like $\mathrm{S}$ globules inside the cell [7-9]. If the system or medium contains selenide $\left(\mathrm{Se}^{2-}\right)$, the amorphous globules will be Se-bearing (S, Se) solid solution [9]. Although Chromatium spp. grows in relatively reduce environment, it can oxidize reduced sulfur $\left(\mathrm{S}^{2-}\right)$ produced by sulfate-reducing bacteria and forms elemental $\mathrm{S}$ inside the cell.

\section{Culture, Sample Preparation, and TEM Experiment}

Sulfate-reducing bacteria used in the experiments were Desulfovibrio desulfuricans DSM 642 which were grown in the following medium as described earlier [5]: To $1000 \mathrm{ml}$ distilled water would be added; Na lactate, $4 \mathrm{ml}$ of a $65 \%$ solution; $\mathrm{NH}_{4} \mathrm{Cl}, 2.0 \mathrm{~g} ; \mathrm{Na}_{2} \mathrm{SO}_{4}, 4.0 \mathrm{~g}$;

$\mathrm{MgSO}_{4} \cdot \mathrm{H}_{2} \mathrm{O}, 2.0 \mathrm{~g} ; \mathrm{K}_{2} \mathrm{HPO}_{4} \cdot 7 \mathrm{H}_{2} \mathrm{O}, 0.5 \mathrm{~g}$; yeast extract, $1.0 \mathrm{~g} ; \mathrm{FeSO}_{4}, 20 \mathrm{mg}$. The $\mathrm{pH}$ was adjusted to 7.4 with $20 \% \mathrm{KOH}$.

Selenium was added from a 0.1 molar solution of $\mathrm{Na}_{2} \mathrm{SeO}_{4}$ and a 0.1 molar solution of $\mathrm{Na}_{2} \mathrm{SeO}_{3}$ to give concentrations of 1 and 100 milimolar (mM) selenate and selenite, respectively. All the cultures were incubated at temperature of $35^{\circ} \mathrm{C}$. Introduction of sulfide was by the addition of a bacterial culture growing in the absence of selenium and producing about 5 micromoles of hydrogen sulfide per ml solution as determined by a sulfide electrode. The specimens for transmission electron microscopy study were prepared by depositing a drop of culture that contained both bacteria and reduced selenium on holey carbon-coated TEM Cu grids.

Samples contained photoautotrophic Chromatium spp. were collected from a top sediment layer of a pond contaminated by Se and sulfate. A sub-sample was incubated

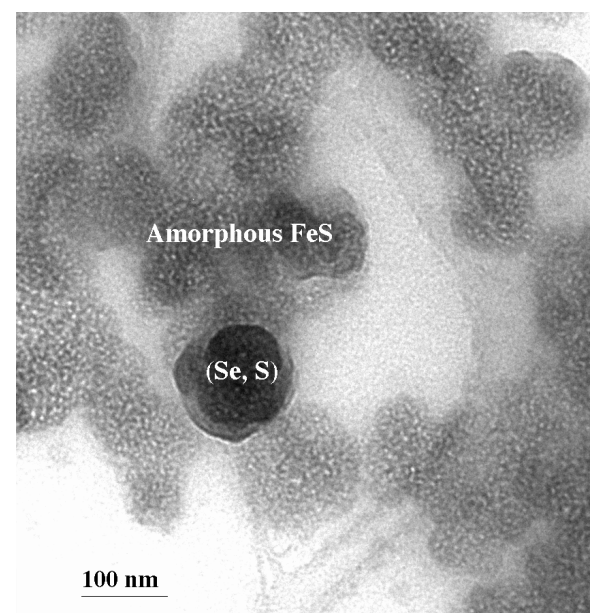

(a) in selenate-bearing solution. Solution from the sediment layer containing bacteria was deposited on holey carboncoated TEM $\mathrm{Cu}$ grids and air dried. All transmission electron microscopy (TEM) and X-ray energy dispersive spectroscopy (EDS) analyses were carried out with a JEOL 2010 HRTEM and Oxford Link ISIS EDS system. A Li-drifted Si detector with ultrathin window was used for collecting EDS spectra. Point-to-point resolution of the HRTEM is $0.19 \mathrm{~nm}$, and accelerating voltage is $200 \mathrm{keV}$.

\section{Results and Discussions}

\subsection{Sulfate-Reducing Bacteria}

The sterile culture medium was transparent, but yellow precipitates were observed in tubes containing $100 \mathrm{mM}$ selenite or $100 \mathrm{mM}$ selenate two days after incubation with $D$. desulfuricans. On the other hand, tubes containing $1 \mathrm{mM}$ selenite and $1 \mathrm{mM}$ selenate formed black precipitates two days after incubation with the bacteria. TEM results show that these black precipitates are amorphous FeS and elemental (Se, S) particles (Figure 1(a)). The composition of the (Se, S) particles is listed in Table 1. The yellow precipitates from $100 \mathrm{mM}$ selenite test tube are amorphous (Se, S) particles (Figure 2(a)). Selected area electron diffraction (SAED) pattern from single particle shows very diffuse rings which indicate amorphous characteristics. Distribution of Se and S within the amorphous particle is relatively homogeneous. It is observed that selenite can alter the shape of the cell, which results in elongated morphology of the bacteria cell [4]. The yellow precipitates from $100 \mathrm{mM}$ selenate test tube are crystalline (Se, S) particles (Figure 2(b)). Selected area electron diffraction (SAED) pattern from single particles produces sharp diffraction spots (Figure 2(b)). The

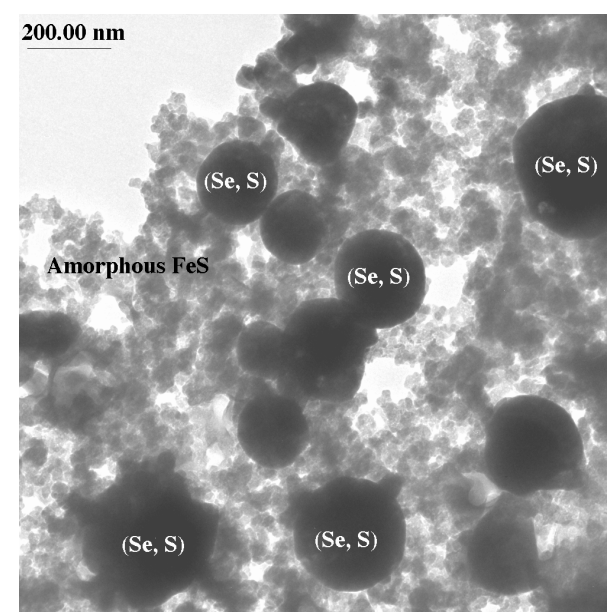

(b)

Figure 1. (a) TEM image showing a (Se, S) particle and dominant amorphous FeS from the medium containing $1 \mathrm{mM}$ selenate after incubation with Desulfovibrio desulfuricans for 2 days; (b) TEM image showing more Se-rich (Se, S) particle and amorphous FeS precipitates from the medium containing $100 \mathrm{mM}$ selenite after incubation with Desulfovibrio desulfuricans for five days. 


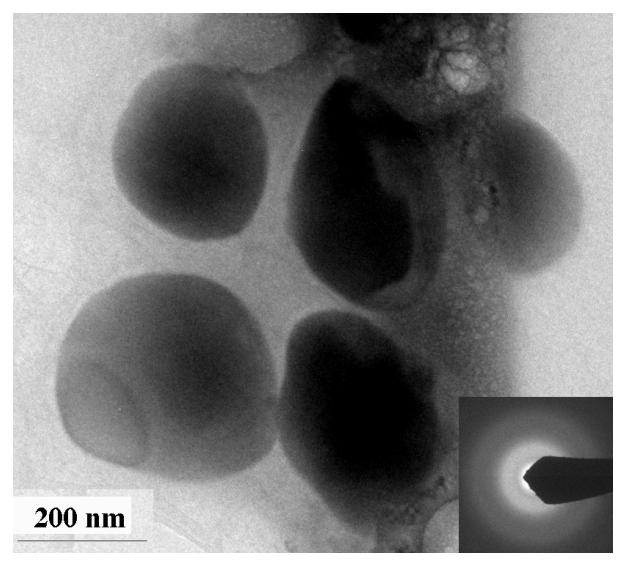

(a)

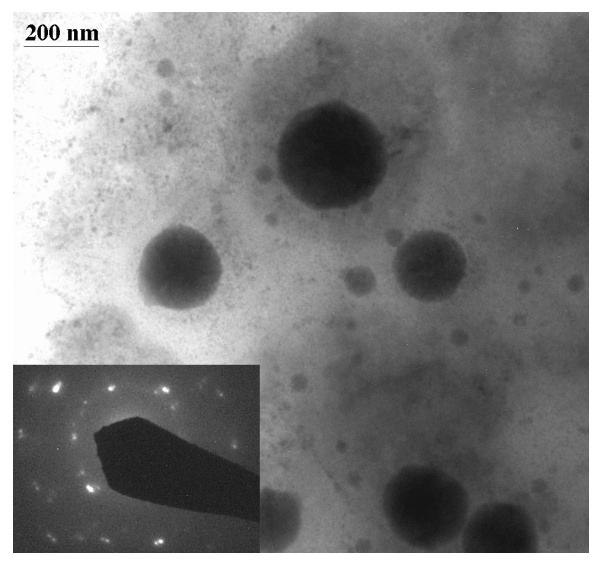

(b)

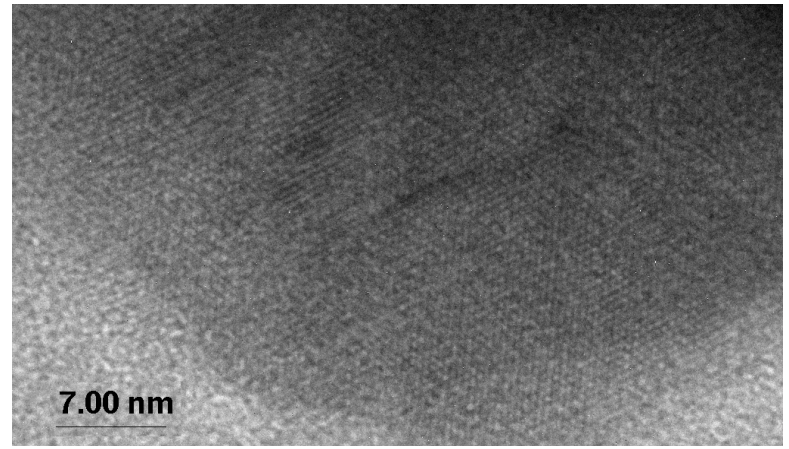

(c)

Figure 2. TEM images showing amorphous Se-rich particles in a medium containing $100 \mathrm{mM}$ selenite after incubation with Desulfovibrio desulfuricans for 2 days (a) and crystalline Se-rich particles from a medium containing $100 \mathrm{mM}$ selenate after incubation with Desulfovibrio desulfuricans for 2 days (b). High-resolution TEM image of a crystalline particle showing lattice fringes (c). Inserted SAED patterns show amorphous character of the (Se, $S$ ) particles from selenite medium and crystalline character of the (Se, S) particles from selenate medium. The crystalline particle is very similar to elemental Se with monoclinic symmetry.

Table 1. Composition of (Se, S) particles.

\begin{tabular}{cc}
\hline Medium condition & $(\mathrm{Se}, \mathrm{S})$ composition \\
\hline $1 \mathrm{mM}$ selenate & $\mathrm{Se}_{0.68} \mathrm{~S}_{0.32}$ \\
$100 \mathrm{mM}$ selenite & $\mathrm{Se}_{0.81} \mathrm{~S}_{0.19}$ \\
$100 \mathrm{mM}$ selenite & $\mathrm{Se}_{0.84} \mathrm{~S}_{0.16}$ \\
$100 \mathrm{mM}$ selenite & $\mathrm{Se}_{0.84} \mathrm{~S}_{0.16}$ \\
$100 \mathrm{mM}$ selenite & $\mathrm{Se}_{0.83} \mathrm{~S}_{0.17}$ \\
$100 \mathrm{mM}$ selenite & $\mathrm{Se}_{0.84} \mathrm{~S}_{0.16}$ \\
$100 \mathrm{mM}$ selenite & $\mathrm{Se}_{0.86} \mathrm{~S}_{0.14}$ \\
$100 \mathrm{mM}$ selenite & $\mathrm{Se}_{0.81} \mathrm{~S}_{0.19}$ \\
$100 \mathrm{mM}$ selenate & $\mathrm{Se}_{0.75} \mathrm{~S}_{0.25}$ \\
$100 \mathrm{mM}$ selenate & $\mathrm{Se}_{0.74} \mathrm{~S}_{0.26}$ \\
$100 \mathrm{mM}$ selenate & $\mathrm{Se}_{0.73} \mathrm{~S}_{0.27}$ \\
$100 \mathrm{mM}$ selenate & $\mathrm{Se}_{0.73} \mathrm{~S}_{0.27}$ \\
$100 \mathrm{mM}$ selenate & $\mathrm{Se}_{0.74} \mathrm{~S}_{0.26}$ \\
$100 \mathrm{mM}$ selenate & $\mathrm{Se}_{0.71} \mathrm{~S}_{0.29}$ \\
$100 \mathrm{mM}$ selenate & $\mathrm{Se}_{0.73} \mathrm{~S}_{0.27}$ \\
$100 \mathrm{mM}$ selenite (5 days) & $\mathrm{Se}_{0.90} \mathrm{~S}_{0.10}$ \\
\hline
\end{tabular}

particles may be single crystal, may be polycrystals. Highresolution TEM images of the crystalline $(\mathrm{Se}, \mathrm{S})$ particles indicate lattice fringes (Figure 2(c)). Distribution of Se and $\mathrm{S}$ within the crystalline particle is homogeneous. Se content in the crystalline particles is less than that in the amorphous (Se, S) particles (Table 1). The possible overall reactions occur in the selenite and selenate solutions are:

$$
\begin{gathered}
2\left\langle\mathrm{CH}_{2} \mathrm{O}\right\rangle_{\text {organic }}+\mathrm{H}_{2} \mathrm{SO}_{4} \rightarrow 2 \mathrm{CO}_{2}+\mathrm{H}_{2} \mathrm{~S}+\mathrm{H}_{2} \mathrm{O} \\
\mathrm{SeO}_{4}^{2-}+3 \mathrm{H}_{2} \mathrm{~S}+8 \mathrm{H}^{+} \rightarrow 3 \mathrm{~S}^{0}+\mathrm{Se}^{0}+4 \mathrm{H}_{2} \mathrm{O} \\
\mathrm{SeO}_{3}^{2-}+2 \mathrm{H}_{2} \mathrm{~S}+6 \mathrm{H}^{+} \rightarrow 2 \mathrm{~S}^{0}+\mathrm{S}^{0}+3 \mathrm{H}_{2} \mathrm{O} \\
3\left\langle\mathrm{CH}_{2} \mathrm{O}\right\rangle+2 \mathrm{SeO}_{4}^{2-} \rightarrow 3 \mathrm{CO}_{2}+2 \mathrm{Se}^{0}+3 \mathrm{H}_{2} \mathrm{O} \\
\left\langle\mathrm{CH}_{2} \mathrm{O}\right\rangle+\mathrm{SeO}_{3}^{2-} \rightarrow \mathrm{CO}_{2}+\mathrm{Se}^{0}+\mathrm{H}_{2} \mathrm{O}
\end{gathered}
$$

In above reactions, $\left\langle\mathrm{CH}_{2} \mathrm{O}\right\rangle$ represents organic. Elemental Se and S actually form solid solution, instead of separated phases. Reaction (1) generates $\mathrm{H}_{2} \mathrm{~S}$ by the sulfate-reducing bacteria $D$. desulfuricans. If elemental $\mathrm{Se}$ is 
in the form of ( $\mathrm{Se}, \mathrm{S})$ solid solution results which involves reactions (2) and (3) only, the (Se, S) particles will be rich in S. If the elemental selenium results from reactions (4) and (5), the product will be almost pure Se. However the observed results show the atomic ratio between $\mathrm{Se}$ and $\mathrm{S}(\mathrm{Se} / \mathrm{S})$ are about $4: 1$ in amorphous particles and 3:1 in crystalline particles (Table 1). It is proposed that reactions (2) and (4) occur in the selenatebearing environment, and reactions (3) and (5) occur in the selenite-bearing environment. However, selenium particles inside the bacteria cell are amorphous [4]. It is proposed that the selenium particles inside the cell are inside plasma membrane. The electron carriers of cytochromes of the bacteria take an important role in the oxidation of organic molecule (electron donor) and reduction of selenite or selenate (electron acceptors). The cytochromes enhance the redox reaction both inside and outside the bacterial cells.

Amorphous Se inside the bacteria cell may be produced in the presence of excess glutathionie (GSH). The selenite reduction inside the cell may follow a series of abiotic reactions proposed by Ganther [10,11]:

$$
\begin{gathered}
\mathrm{GSH}+\mathrm{H}_{3} \mathrm{SeO}_{3} \rightarrow \mathrm{GSSeO}_{2} \mathrm{H}+\mathrm{H}_{2} \mathrm{O} \\
\mathrm{GSH}+\mathrm{GSSeO}_{2} \mathrm{H} \rightarrow \mathrm{GSSeSG}+\mathrm{H}_{2} \mathrm{O} \\
\mathrm{O} \\
\mathrm{GSH}+\mathrm{GSSeSG} \rightarrow \mathrm{GSSeSG}+\mathrm{GSOH} \\
\mathrm{NADPH}+\mathrm{H}^{+}+\mathrm{GSSeSG} \stackrel{\mathrm{GSH} \text { reductase }}{\longrightarrow} \\
\mathrm{GSSeH}+\mathrm{GSH}^{\mathrm{O}}+\mathrm{NADPH}{ }^{+} \\
\mathrm{GSSeH} \stackrel{\text { spontaneous }}{\longrightarrow} \mathrm{GSH}+\mathrm{Se}^{0}
\end{gathered}
$$

The reduction of selenite by a strain of Pseudomonas has been proposed to proceed according to mechanism indicated in reactions (6) - (10) [12].

When the media containing $100 \mathrm{mM}$ selenite was inoculated with $D$. desulfuricans and incubated for five days, black precipitates due primary to amorphous FeS formed, and the yellow precipitates become orange colored. TEM results indicate $(\mathrm{Se}, \mathrm{S})$ particles and amorphous FeS precipitates (Figure 1(b)). The (Se, S) particles become crystalline and more Se-rich (Table 1). It is proposed that the bacteria reduce $\mathrm{S}$ in the $(\mathrm{Se}, \mathrm{S})$ particles, which combines with $\mathrm{Fe}^{2+}$ to form amorphous $\mathrm{FeS}$. The reaction may be expressed as:

$$
\begin{aligned}
& \mathrm{m}\left\langle\mathrm{CH}_{2} \mathrm{O}\right\rangle+2\left(\mathrm{Se}_{1-\mathrm{m}} \mathrm{S}_{\mathrm{m}}\right)_{\mathrm{amph}}+\mathrm{H}_{2} \mathrm{O} \rightarrow \\
& 2 \mathrm{~m} \mathrm{HS}^{-}+2(1-\mathrm{m}) \mathrm{Se}_{\text {cryst }}^{0}+\mathrm{m} \mathrm{CO}_{2}+\mathrm{H}^{+}
\end{aligned}
$$

and

$$
\mathrm{Fe}^{2+}+\mathrm{HS}^{-} \rightarrow \mathrm{FeS}+\mathrm{H}^{+}
$$

The Desulfovibrio desulfuricans bacterium is able to enrich $\mathrm{Se}$ in the (Se, S) solid solution particles. The process also results in the transformation from amorphous (Se, S) particles to polycrystalline Se particles. We can approximately illustrate the relationship between the color of the particles and Se content in the particles as:

$$
\underset{\text { Light yellow }}{\mathrm{S}} \rightarrow \underset{\text { Yellow }}{(\mathrm{S}, \mathrm{Se})} \rightarrow \underset{\text { Orange }}{(\mathrm{Se}, \mathrm{S})} \rightarrow \underset{\text { Red }}{\mathrm{Se}}
$$

It is proposed that the reduction of selenate and selenite is associated with cytochrome in the cell through metabolism of the cell. The function of cytochrome in the outer membrane would be to participate in detoxification and in this case would be reduction of selenate through transferring electrons from the organic molecules to selenate ions (Figure 3). Possible overall reactions occur in the selenate reduction is:

$$
\begin{aligned}
& 2\left\langle\mathrm{CH}_{2} \mathrm{O}\right\rangle+\mathrm{SeO}_{4}^{2-} \stackrel{\text { Cells of } D \text {. desulfuricans }}{\longrightarrow} \\
& 2 \mathrm{HCO}_{3}^{-}+\mathrm{Se}_{(\mathrm{S})}+2 \mathrm{H}_{2} \mathrm{O}
\end{aligned}
$$

In above reactions, $\left\langle\mathrm{CH}_{2} \mathrm{O}\right\rangle$ represents organic acids such as lactic acid or pyruvic acid that may serve as electron donors. Sulfate-reducing bacteria have several different molecular forms of c-type cytochromes. D. desulfuricans has a tetraheme $\left(c_{3}\right)$ c-type cytochrome in the periplasmic space between the outer membrane and plasma membrane [13]. D. desulfuricans has two additional soluble c-type cytochromes that are either hexaheme or dodecaneheme proteins. Cytochromes have been reported in the outer membrane of $D$. vulgaris [14] and it would be consisted to assume that cytochromes are present in the outer membrane of $D$. desulfuricans. Hydrogenase is found in the periplasmic space of sulfate-reducers [13].

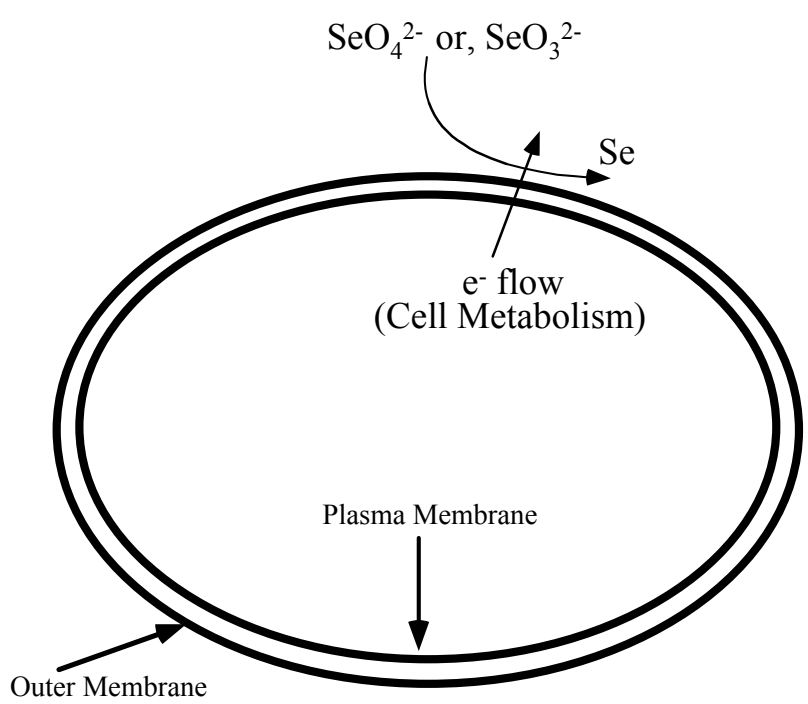

Figure 3. A model depicting for the reduction of selenate and selenite. 


\subsection{Sulfide-Oxidizing Bacteria}

TEM images of the environmental Chromatium spp. samples show S-rich globules inside the bacteria cell. The globules are amorphous and dominated by $\mathrm{S}$ with small amount of Se. EDS results from the globules show that the globules are composed of S-rich and more S-rich layers (Table 2). The overall composition of the intracellular globules is S-rich (Table 2, Figure 4(c)). There are also some much smaller Se-rich particles on the surface of the bacteria (Figure 4(a)). These particles are crystalline selenium with small amount of S (Figure 4(b)). It is proposed that the composition of these particles is controlled by the composition of solution, that is the equilibrium reaction of:

$$
\mathrm{Se}_{\text {solid }}^{\mathbf{0}}+\mathrm{HS}^{-}=\mathrm{S}_{\text {solid }}^{\mathbf{0}}+\mathrm{HSe}^{-}
$$

Such kind of Se particles may result from reduction of selenite or selenate by bacteria-produced $\mathrm{H}_{2} \mathrm{~S}$. However, the composition of the S-rich globules inside the cells is controlled by the alive bacteria. The bacteria prefer $\mathrm{S}$, instead of Se. The selenium in the S-rich globules results from diffusion of $\mathrm{H}_{2} \mathrm{Se}$ through membrane. It is proposed that the layer containing less Se formed during photosynthetic active (such as day) period, and the layer containing more Se formed during respiration active (such as night) period. The zonation textures of the globules are illustrated in Figure 4. The possible reactions for the formation of the S-rich globules are:

$$
\mathrm{CO}_{2}+2 \mathrm{HS}^{-} \stackrel{\text { light }}{\longrightarrow} 2 \mathrm{~S}^{0}+\left\langle\mathrm{CH}_{2} \mathrm{O}\right\rangle_{\text {organic }}+\mathrm{O}^{2-}
$$

and the diffusion through membrane of reaction (14):

$\mathrm{HS}^{-}$is produced by any sulfate-reducing bacteria. The S-rich globules are at the position between outer membrane and plasma membrane (Figure 5).

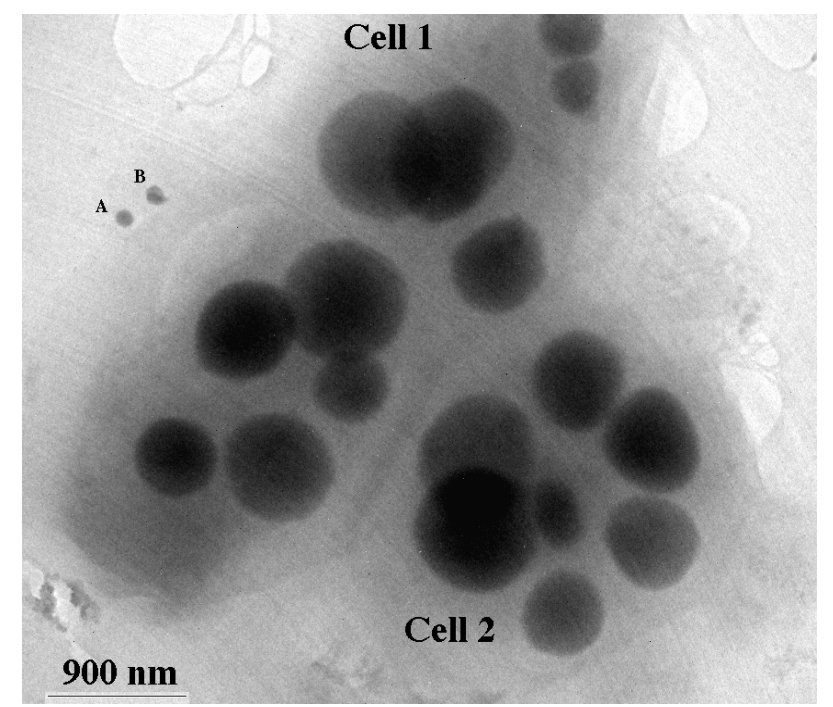

(a)

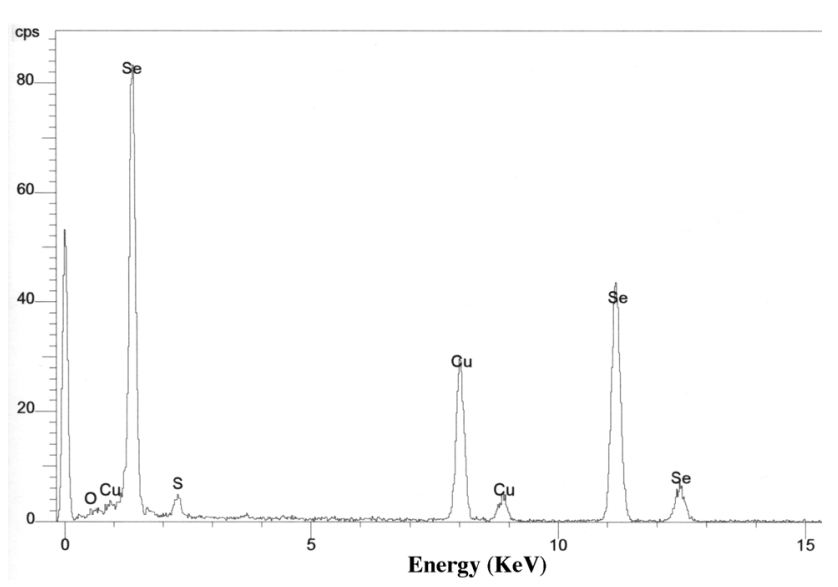

(b)

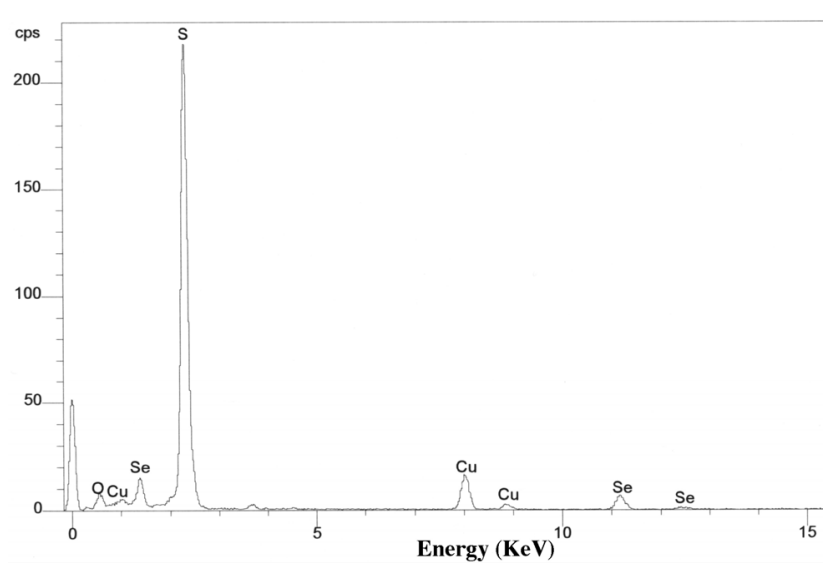

(c)

Figure 4. TEM image showing two Chromatium spp. bacterial cells with S-rich globules inside the cells (a). There are two small Se-rich particles (A and B of (a)) on a bacterial cell. EDS spectra from a Se-rich particle (b) on the surface of the cell and a S-rich globule (c) inside the cell. $\mathrm{Cu}$ peaks result from $\mathrm{Cu}$ grid holding the specimen. 


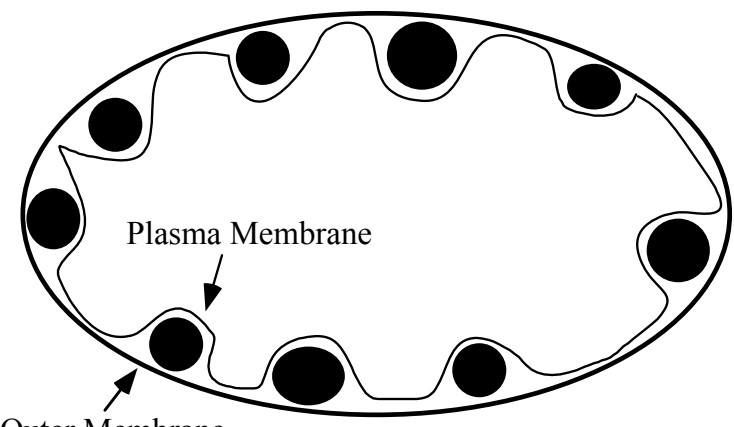

Outer Membrane

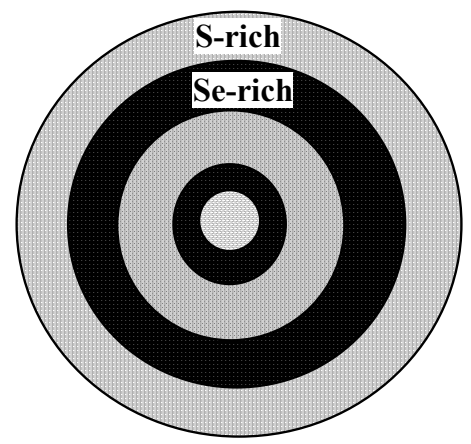

Figure 5. A diagram showing the S-rich globules between outer membrane and plasma membrane (upper). The Sebearing globules have zonation structure that is composed of S-rich layer and relatively S-poor layer.

Table 2. Composition of (S, Se) globules.

\begin{tabular}{cc}
\hline & Globule 1 (small) \\
\hline Whole globule & \\
Center & $\mathrm{S}_{0.82} \mathrm{Se}_{0.18}$ \\
& $\mathrm{~S}_{0.71} \mathrm{Se}_{0.29}$ \\
& $\mathrm{~S}_{0.79} \mathrm{Se}_{0.21}$ \\
Edge & $\mathrm{S}_{0.79} \mathrm{Se}_{0.21}$ \\
& $\mathrm{~S}_{0.80} \mathrm{Se}_{0.20}$ \\
\hline Center & Globule 2 (large) \\
& $\mathrm{S}_{0.86} \mathrm{Se}_{0.16}$ \\
& $\mathrm{~S}_{0.83} \mathrm{Se}_{0.17}$ \\
& $\mathrm{~S}_{0.75} \mathrm{Se}_{0.25}$ \\
& $\mathrm{~S}_{0.72} \mathrm{Se}_{0.28}$ \\
& $\mathrm{~S}_{0.81} \mathrm{Se}_{0.19}$ \\
Edge & $\mathrm{S}_{0.86} \mathrm{Se}_{0.14}$ \\
\hline Particles on the cell surface \\
\hline Particle B & $\mathrm{S}_{0.02} \mathrm{Se}_{0.98}$ \\
\hline
\end{tabular}

\section{Conclusion}

Transmission electron microscopy revealed that the sulfate-reducing bacteria of the species Desulfovibrio desulfuricans growing in selenite- or selenate-bearing media can produce yellow spherical $(\mathrm{Se}, \mathrm{S})$ sub-micro particles precipitated outside the cells. It is assumed that low potential electron carriers, such as cytochromes from the bacteria mediate the redox reaction. Amorphous-like Serich spherical particles may also occur inside the bacteria cell. The bacteria can also reduce $\mathrm{S}$ in the $(\mathrm{Se}, \mathrm{S})$ solid solution particles and make the particles more Se-rich. This enrichment process will also include a phase transformation from amorphous (Se, S) to polycrystalline Se. The further reduced $\mathrm{S}$ combines with $\mathrm{Fe}$ and forms precipitates of amorphous FeS. Photoautotrophic Chromatium spp. is able to oxidize sulfide $\left(\mathrm{S}^{2-}\right)$ by using light. The bacteria grown in sulfide- and selenide-bearing system show amorphous-like $(\mathrm{S}, \mathrm{Se})$ globules inside the cells. Compositional zonation in the $(\mathrm{S}, \mathrm{Se})$ globules occur in Chromatium spp. It is proposed that the layer containing less Se is formed during active photosynthesis, while the layer containing more Se is formed during night when respiration occurs. It is proposed that both Desulfovibrio desulfuricans and Chromatium bacteria are able to immobilize and collect selenium from selenate and/or selenite and selinide respectively in the forms of elemental selenium and ( $\mathrm{Se}, \mathrm{S}$ ) solid solutions.

\section{Acknowledgements}

This research was supported in part by NASA Astrobiology Institute (N07-5489), and grants from DOE-WERC, MARC and IMSD grants from National Institute of Health.

\section{REFERENCES}

[1] E. P. Painter, "The Chemistry and Toxicity of Selenium Compounds, with Special Reference to the Selenium Problem," Chemical Reviews, Vol. 28, No. 2, 1941, pp. 179213. doi: $10.1021 / \mathrm{cr} 60090 \mathrm{a} 001$

[2] R. S. Oremland, J. T. Hollibaugh, A. S. MaestPresser, T. S. Presser, L. G. Miller and C. W. Culbertson, "Selenate Reduction to Elemental Selenium by Anaerobic Bacteria in Sediments and Culture: Biogeochemical Significance of a Novel, Sulfate-Independent Respiration," Applied and Environmental Microbiology, Vol. 55, No. 9, 1989, pp. 2333-2343.

[3] N. A. Steinberg and R. S. Oremland, "Dissimilatory Selenate Reduction Potentials in a Diversity of Sediment Types," Applied and Environmental Microbiology, Vol. 56, No. 11, 1990, pp. 3550-3557.

[4] F. A. Tomei, L. L. Barton, C. L. Lemanski, T. G. Zocco, N. H. Fink and L. O. Sillerud, "Transformation of Selenate and Selenite to Elemental Selenium by Desulfovibrio desulfuricans," Industrial Microbiology, Vol. 14, No. 3-4, 1995, pp. 329-336.

[5] M. D. Tucker, L. L. Barton and B. M. Thompson, "Reduction of Cr, Mo, Se and U by Desulfovibrio desulfuricans Immobilized in Polyacrylamide Gels," Industrial Microbiology, Vol. 20, No. 1, 1998, pp. 13-19.

[6] D. R. Lovley, "Dissimilatory Metal Reduction," Annual Review of Microbiology, Vol. 47. 1993, pp. 263-290. 
doi:10.1146/annurev.mi.47.100193.001403

[7] R. Steudel, "On the Nature of the Elemental Sulfur $\left(\mathrm{S}^{0}\right)$ Produced by Sulfur-Oxidizing Bacteria-A Model for $\mathrm{S}^{0}$ Globules," In: H. G. Schlegel and B. Bowien, Eds., Autotropic Bacteria, Springer-Verlag, Berlin, 1989, pp. 289304.

[8] N. Pfennig and H. G. Trüper, "The Family Chromatiaceae," In: A. Balows, Ed., The Prokaryotes, Vol. 4, 2nd Edition, Springer-Verlag, New York, 1992, pp. 3200-3221.

[9] D. C. Nelson, W. H. Casey, J. D. Sison, E. R. Mack, A. Ahmad and J. S. Pollack, "Selenium Uptake by SulfurAccumulating Bacteria," Geochimica et Cosmochimica Acta, Vol. 60, No. 18, 1996, pp. 3531-3539. doi:10.1016/0016-7037(96)00221-9

[10] H. E. Ganther, "Selenotrisulfides. Formation by the Reaction of Thiols with Selenious Acid," Biochemistry, Vol. 7, No. 8, 1968, pp. 2898-2905. doi:10.1021/bi00848a029
[11] H. E. Ganther, "Reduction of the Selenotrisulfide Derivative of Glutathione to a Persulfide Analog by Gluthathione Reductase," Biochemistry, Vol. 10, No. 22, 1971, pp. 4089-4098. doi:10.1021/bi00798a013

[12] R. C. Blake, D. M. Choate, S. Bardhan, N. Revis, L. L. Barton and T. G. Zocco, "Chemical Transformation of Toxic Metals by a Pseudomonas Strain from Wastes Site," Environmental Toxicology and Chemistry, Vol. 12, No. 8, 1993, pp. 1365-1376. doi:10.1002/etc.5620120806

[13] G. Fauque, J. Le Gall and L. L. Barton, "Sulfate-Reducing and Sulfur-Reducing Bacteria," In: J. M. Shively and L. L. Barton, Eds., Variations in Autotrophic Life, Academic Press, London, 1991, pp. 271-339.

[14] F. V. Kloeke, R. D. Bryant and E. J. Laishley, "Localization of Cytochromes in the Outer Membrane of Desulfovibrio vulgaris (Hildenborough) and Their Role in Anaerobic Biocorrosion," Anaerobe, Vol. 1, No. 6, 1995, pp. 351-358. doi:10.1006/anae.1995.1038 